\begin{abstract}
"Mircea cel Batran" Naval Academy Scientific Bulletin, Volume XIX - 2016 - Issue 1
Published by "Mircea cel Batran" Naval Academy Press, Constanta, Romania /I The journal is indexed in:

PROQUEST / DOAJ / DRJI / JOURNAL INDEX / I2OR / SCIENCE LIBRARY INDEX / Google Scholar / Crossref /

Academic Keys I ROAD Open Access / OAJI / Academic Resources / Scientific Indexing Services / SCIPIO
\end{abstract}

\title{
THE USE OF AMINO ACIDS BEFORE EFFORT
}

\author{
Virgil ENE-VOICULESCU ${ }^{1}$ \\ Carmen ENE-VOICULESCU ${ }^{2}$ \\ IOn LAZĂR ${ }^{3}$ \\ ${ }^{1}$ Professor Ph.D., Naval Academy, Constanta, Romania \\ ${ }^{2}$ Professor Ph.D., "Ovidius" University, Constanta, Romania \\ ${ }^{3}$ Lecturers Ph.D., Naval Academy, Constanta, Romania
}

\begin{abstract}
The present paper is based on the requisite that the administering of amino acids to students participating in the National Contest of Chemistry leads to increased attention before important competitions as such. The paper briefly presents the role of attention and memory in obtaining good results in competitions as a consequence of administering effort sustaining substances.
\end{abstract}

Keywords: amino acids, ergo genetic substances

\section{INTRODUCTION}

The act of attention consists of emphasizing, both in perception and thinking, certain objects, being accompanied by concurrent distractions from the others. From a physiological point of view, this unity is based upon certain localization in the central nervous system of the excitement and inhibition processes. Nowadays, it is considered that the physiological basis of the attention acts is represented by the existence of a centre of optimal excitability between certain points of the cortex and the decrease of excitability of the other points. This takes place by virtue of the law of negative induction according to which the excitability of certain zones in the cortex leads to the inhibition of other zones. F.C. Bakker, M.S. Boschker, T. Chung, 1996, studied the effects of the retroactive interferences of the action speed, mentally imagined. Understanding and selfawareness, as psychical processes have as a starting point the self image. This image is composed of all past experiences, from one's birth or the starting point of educational process to the present moment. F.C. Bakker's study, 1996, had as main purpose to discover the speed effects of an imaginary activity upon the studying pace.

The phenomenon known as the "assimilation tendency" represents an answer to the studies that had been conducted until that moment with regard to the issue of imaginative action. Annett, 1995 and A. Paivio, 1991, demonstrated that no additive effect of verbal identification upon the supposed action speed was found. Extrapolating the conclusions of J.J. Janssen' and A.A. Sheikh's study, 1994, we could conclude that any student facing a very important competition has to be very careful about what he thinks of, because inappropriate images related to a certain aim could diminish the expected performance. R. A. Schmidt, 1991, asserted that if an automatism regarding the data processing is reached, a lot of

DOI: 10.21279/1454-864X-16-I1-066

(c) 2015. This work is licensed under the Creative Commons Attribution-Noncommercial-Share Alike 4.0 License. actions can take place not only very quickly, but also at the same time with other activities, even without destroying the performance. It is known that the brain needs to be administered glucose daily in order to maintain the optimal excitability level required to take over and process the received data. It is also acknowledged that a small portion of the glucose is turned into amino acids through the process of transamination and the pyruvic acid is turned into alanine. At its turn, the alanine is turned into serine and serine into glycocoll. The acetyl radicals resulted from the glucose degradation enter the Krebs cycle, resulting into getoglutaric acids which, through amination turn into glutamic and oxalacetic acid.

Thus, the acetyl radical contributes to the biosynthesis of the carbonic skeleton contained in many non essential amino acids. Moreover, the glucose transformed in compounds of muco polysaccharide enters the structure of the conjunctive tissue of the: cellular membrane, the cartilages and the ligaments. The energy from the carbonic chain which is released during their metabolisation is stored in the ATP macroergic phosphates.

In the case of the oxidation of glucose from the Krebs cycle, approximately $65 \%$ from the potential chemical energy contained in the molecule of these substances is stored in the macroergic phosphate chains of the ATP while the rest of $35 \%$ is turned into heat which is lost, in our case, through the effort of such (extrapolated from J. H., Wilmore, D. L., Costill, 1994, M. L.. Malina, C. Bouchard, 1991). A. Zani and B. Rosi, 1991, think that the proper method to research the mental processes during the physical effort and consequently during the speed efforts is the cognitive psycho-physiology through which the mental processes must not be studied separated from the brain in the case in which two types of potentials appear. 


\begin{abstract}
"Mircea cel Batran" Naval Academy Scientific Bulletin, Volume XIX - 2016 - Issue 1
Published by "Mircea cel Batran" Naval Academy Press, Constanta, Romania /I The journal is indexed in: PROQUEST / DOAJ / DRJI / JOURNAL INDEX / I2OR / SCIENCE LIBRARY INDEX / Google Scholar / Crossref /

Academic Keys I ROAD Open Access / OAJI / Academic Resources / Scientific Indexing Services / SCIPIO
\end{abstract}

Thus, the representation of stimuli in the central nervous system is due to the above mentioned The correlated potentials with the events (PCE) are the ones which are in correlation with the success of certain cognitive events such as: the focusing of attention, the data processing, the rearranging of short-term memory based on the results of processing, the decision for a possible execution of a movement action or the preparation of the movement. The PCE method was used by the above mentioned authors in order to study the cognitive and focusing processes in the case of children and teenagers aged 10, 13 and 18. In order to study the interaction of the growing up process of the brain in the case of the development of attention, the brain potentials have been deducted from the partial, central and frontal zones.

The above mentioned authors have reached the following conclusions:

$1^{*}$ the frontal zones, which participate more in the attention processes, reach maturity only at the age of 12-13;

$2^{*}$ children of 10 have proved to be less efficient at the level of attention focusing, which in fact means turning of the provisions of attention towards the present data, independent of its relevance regarding that action;

$3^{\star}$ all 10-year old children, when discussing their ability to distinguish between the relevant and irrelevant data for a certain problem, are as capable as grown-ups. This fact has been acknowledged in the case of reaction, at 10-year old children who were able to provide very quick motor answers to relevant problems.

This conclusion confirms the hypothesis according to which a weaker performance in the case of children's attention is caused by the inhibition of the motor reaction.

Ambition and motivation are indispensable in the life of a sprinter, as long as they are in accordance with the other essential factors, which, D. Swartz, 1980 consider to be:

- the adequate physical condition;

- the appropriate technique;

- way of life (sleeping hours, food, etc).

If these factors are considered, the mental barriers which limit the physical performances can be overtaken. The same author considers that success in a competition is due to self consciousness, through one's self-image as a winner. potentials (PE).

These physical capacities can be emphasized through attention visualization-concentration on a future event which resides in the one's subconscious.

Although science has proved that the subconscious do not differentiate between real and imaginary events, visualization has to be done at the first person and during the competition day: "I know, I can, I can be the first," etc.

Starting from these premises, in our research, we want to identify the role of amino acids during the pre-event phase of children participating in the Chemistry contest. The 6 (six) participating children in the Chemistry contest at the county level were daily (the day of the contest was also included) administered 6 (six) pills of Amino2000 during the whole experiment (30 days before the county contest) in comparison with a sample of children who were not administered any pills. It is worth mentioning that the parents and children accepted the experiment unanimously. Amino 2000 is a quality product which regenerates the body tissues, provides the body with energy and regulates several important metabolic processes in the human body. The product contains among others the amino acid called tyrosine whose role is emphasized in the specialized literature, as well as cystein protein. (Topală C., Baciu I., Paraschivescu C., Drăghici C., 2002; Gabrus I.R., 2005).

\section{THE RESEARCH HYPOTHESIS}

We consider that administering 6 pills of amino acids (Amino 2000) contributes to the increase of children's efficiency in important competitions. The program should be designed according to the following scheme (if they are administered amino acids): 30 days before the competition 2 pills three times a day: at 8 a.m. in the morning before the classes start, before lunch at noon and at 5 p.m. before the specific training program whether in the Excellency Center/Chemistry Center or during the individual training program.

\section{MATERIAL AND METHOD}

The present paper is an experiment of a transversal type with regard to the role of amino acids in maintaining the attention focused during the educational effort in the case of students participating in the Chemistry contest. The experiment lasted between the $15^{\text {th }}$ of January and $15^{\text {th }}$ of February 2005. Table number 1 contains the results obtained by the two samples at the county contest. 
"Mircea cel Batran" Naval Academy Scientific Bulletin, Volume XIX - 2016 - Issue 1

Published by "Mircea cel Batran" Naval Academy Press, Constanta, Romania // The journal is indexed in: PROQUEST / DOAJ / DRJI / JOURNAL INDEX / I2OR / SCIENCE LIBRARY INDEX / Google Scholar / Crossref / Academic Keys / ROAD Open Access / OAJI / Academic Resources / Scientific Indexing Services / SCIPIO

Table 1.

\begin{tabular}{|l|c|}
\hline & The average mark at the county contest \\
\hline Experimental sample & $9,2 \pm 0,2$ \\
\hline Control sample & $8,5 \pm 0,7$ \\
\hline
\end{tabular}

Similar studies about the role of amino acids during physical training have been conducted but there are not any clear direct references to the influence of amino acids upon the students' intellectual performances. There is a study published in Journal Sports Med. Feb.19 (2):82-6 whose authors advocate the supposition according to which the administering of 1-1,8 $\mathrm{g}$ protein $/ \mathrm{kg}$ is recommended for a person during the training program (Van Hall, G, Saris, WH, Wagenmakers, A. J., 1998).
Another article published in Dynamic Chiropractic February 11, 1994, Volume 12, Issue 04, by G. Douglas Andersen, states that administering amino acids is beneficial only after injuries, weight loss, strength loss, etc. Another statement of the above mentioned study underlines the idea that amino acids do not influence the performance if they are administered for a week or less than that, although the producers of such ergogenic substances contradict this idea.

\section{CONCLUSIONS}

The research hypothesis has been confirmed. The analysis of the registered parameters reveals the progress of the experimental sample which is $0.7 \%(9.2)$ higher than the control sample (8.5). The final conclusion of the research conducted during the four weeks of training is that the role of amino acids is relevant in obtaining educational performances.

\section{BIBLIOGRAPHY}

[1] Andersen, D.G., 1994, Amino Acids Supplements: Sports Update, in Dynamic Chiropractic February 11, Volume 12, Issue 04.

[2] Annett, J., 1995, Imagery and motor performance, Editorial overview, British Journal of Psychology, 86, p: 161-167.

[3] Bakker, F.C., Boschker, M. S. J., Chung, T., 1996, Change in muscular activity while imagining weight lifting using stimulus or response propositions, Journal of Sport and Exercise Psychology, 18, p: 313 -324.

[4] Costil, D.L., Miller, S.J., Myers, W.C., Kehoe, F.M. and Hoffman, W. M., 1968, Relationship among selected tests of explosive leg strength and power. Research Quarterly, 39, p: 785-787.

[5] Gabrus I.R., October 2005, New Tendencies in Bioinorganic Chemistry, The Chemistry Magazine, Bucharest

[6] Lesmes, G.R., Benham, D.W., Costill, D.L., Fink, W.J, 1983, Glycogen Utilization in Fast and Slow Twitch Muscle Fibers During Maximal Isokinetic Exercise, Annals of Sports Medicine, 1 p: 106-107.

[7] Malina, M. L., Bouchard, C., 1991, Growth maturation and physical activity, Illinois, p: 205-208.

[8] Paivio, A., 1991, Images in Mind: The Evolution of a Theory, Harvester -Wheatsheaf, New-York

[9]Topală C., Baciu I., Paraschivescu C., Drăghici C., January 2002, New derivatives of N-acetil-L-tirosinei, The Chemistry Magazine, Bucharest.

[10] Swartz, D., 1980, Psychical aspects: a key-word for performance, Track technique, S.U.A. p: 78, 24752477.

[11] Van Hall G, Saris WH, Wagenmakers AJ., February 1998, Effect of carbohydrate during prolonged exercise and recovery, Int. Journal of Sports Medicine, 19(2) p: 82-6.

[12] Wilk, K.E., Voight, M.L., Keirns, M.A., Gambetta, V., Andrews, J.R., Dillmam, C.J., 1993, Stretchshortening drills for the upper extremities: Theory and clinical application. Journal of Orthopedic and Sports Physical Therapy, 17(5), p: 225-239.

[13] Wilmore, J. H., Costill, D. L., 1994, Physiology of sport and exercise, Human Kinetics, p: 96-106. 